\title{
Linking local wildfire dynamics to pyroCb development
}

\author{
R. H. D. McRae ${ }^{1}$, J. J. Sharples ${ }^{2}$, and M. Fromm ${ }^{3}$ \\ ${ }^{1}$ Australian Capital Territory Emergency Services Agency, Canberra, Australia \\ ${ }^{2}$ University of New South Wales, Canberra, Australia \\ ${ }^{3}$ US Naval Research Laboratory, Washington, USA
}

Correspondence to: R. H. D. McRae (rick.mcrae@act.gov.au)

Received: 17 September 2014 - Published in Nat. Hazards Earth Syst. Sci. Discuss.: 2 December 2014

Revised: - - Accepted: 1 February 2015 - Published: 5 March 2015

\begin{abstract}
Extreme wildfires are global phenomena that consistently result in loss of life and property and further impact the cultural, economic and political stability of communities. In their most severe form they cause widespread devastation of environmental assets and are capable of impacting the upper troposphere/lower stratosphere through the formation of a thunderstorm within the plume. Such fires are now often observed by a range of remote-sensing technologies, which together allow a greater understanding of a fire's complex dynamics.

This paper considers one such fire that burnt in the Blue Mountains region of Australia in late November 2006, which is known to have generated significant pyrocumulonimbus clouds in a series of blow-up events. Observations of this fire are analysed in detail to investigate the localised processes contributing to extreme fire development. In particular, it has been possible to demonstrate for the first time that the most violent instances of pyroconvection were driven by, and not just associated with, atypical local fire dynamics, especially the fire channelling phenomenon, which arises due to an interaction between an active fire, local terrain attributes and critical fire weather and causes the fire to rapidly transition from a frontal to an areal burning pattern. The impacts of local variations in fire weather and of the atmospheric profile are also discussed, and the ability to predict extreme fire development with state-of-the-art tools is explored.
\end{abstract}

\section{Introduction}

Over the last decade south-eastern Australia has experienced a number of extreme wildfire events. These include the January 2003 Alpine fires (Nairn, 2003), the 2006-2007 Great
Divide fires (Smith, 2007), the 2009 Victorian fires (Teague et al., 2010) and also multiple fires in more recent years that are still under review. These fires caused widespread destruction of assets (both natural and anthropogenic) and multiple fatalities. While such fires are undoubtedly tragic, they do offer rare opportunities to better understand the dynamics and impacts of extreme wildfires. Of particular interest in this context is the development of pyroconvective plumes that inject smoke and other wildfire emissions high into the atmosphere.

The development of these vigorous plumes, which manifest as pyrocumulus or pyrocumulonimbus (pyroCb) (American Meteorological Society, 2013), signals a transition in fire development from what is primarily a surface phenomenon to a coupled fire-atmosphere phenomenon (Potter, 2002; McRae and Sharples, 2011), in which the fire is able to interact with upper levels of the atmosphere (i.e. the mixed layer and above). Fires that make such a transition may access stronger winds and very dry air, which if returned to the surface (e.g. through convective mixing) can lead to elevated levels of fire behaviour and rates of spread (Potter et al., 2007; Mills, 2005, 2008). These fires would therefore be difficult to suppress and would very likely do extensive damage to any assets they impacted (McRae and Sharples, 2011).

The injection height of smoke plumes from wildfires also has direct bearing on their effects on air quality and climate, as it is a major factor governing downwind dispersal (Jost et al., 2004; Mazzoni et al., 2007; Kahn et al., 2008). In the most significant instances of pyroconvection, emissions from wildfires can be injected into the lower stratosphere with subsequent global-scale impacts on atmospheric chemistry (Fromm et al., 2004; Trentmann et al., 2006; Rosenfeld et al., 2007). Stratospheric injection of pyrogenic aerosols could 
also play an important part in the interaction between wildfire occurrence and climatic warming (Fromm et al., 2004; Jost et al., 2004). Large fire plumes offer a direct transport path between the planetary boundary layer and the stratosphere, which is not fully captured by large-scale atmospheric transport models (Jost et al., 2004).

In their analysis of the 2003 Canberra bushfires, Sharples et al. (2012) demonstrated several cases where interactions between strong winds and rugged topography resulted in rapid wildfire development. The resulting process, which they termed "fire channelling", resulted in a transition from the usual frontal burning pattern to an areal burning pattern caused by a combination of rapid lateral fire propagation (transverse to the prevailing winds) and downwind infill by short- to medium-range spotting. For the Flea Creek event (Sharples et al., 2012, p. 288) they showed a direct link between the lateral spread and the pyroCb development, which Fromm et al. (2006) has shown reached $15 \mathrm{~km}$ a.g.l. A series of large fires merged on a rugged landscape on a day of elevated fire danger, eventually covering over 90000 ha in $3 \mathrm{~h}$. Line-scan data showed that deep flaming in numerous locations was primarily caused by the lateral spread associated with fire channelling. There was a close association of this with pyroCb development, but in such a complex setting clear linkages have not yet been demonstrated.

PyroCb events such as those near Canberra in 2003 are at the most extreme end of the pyroconvective spectrum. Indeed such high-level smoke injection events hardly feature at all in previous studies of fire plumes (e.g. Lavoue et al., 2000; Val Martin et al., 2010). Fromm et al. (2010) discuss the global climatology of pyroCb events and note in particular the small number of published studies. Since 2001 there have been at least 30 instances of significant pyroCb occurrence in Australia either demonstrated or inferred from their injection of aerosols into the upper troposphere/lower stratosphere (Tables A1 and A2). While there is the possibility that additional pyroCbs have occurred in the past in association with significant bushfires that predate the technology necessary to formally detect them, this tabulation of pyroCb occurrence is informative both for the satellite and pre-satellite era. The recent frequency of pyroCb occurrence in Australia necessitates ongoing monitoring and study.

Fromm et al. (2012) analysed pyroCb occurrence associated with two of the fires that occurred in eastern Australia during the spring and summer of 2006/2007, at locations shown in Fig. 1a. The so-called Grose Valley and Wollemi fires were notable due to the fact that their behaviour escalated quasi-simultaneously in the late morning rather than in the late afternoon when this typically occurs (Fromm et al., 2010).

Based on remotely sensed data from a range of satellites and weather radar and surface and profile data from official weather observation sites, Fromm et al. (2012) concluded that the factors of significance for the development of the pyroconvection were significant departures from the norm in boundary layer temperature (as indicated by the elevated value of the continuous Haines (C-Haines) Index) and wind speed. They also noted that neither factor alone was deterministic, reflecting a general need to further scrutinise the local drivers of the extreme fire behaviour.

The present paper therefore extends the study of Fromm et al. (2012) by exploiting data recorded for the Grose Valley fire by an airborne multispectral line scanner (Cook et al., 2009), which provides critical insights into the wildfire dynamics. The combination of time-stamped, spatially rectified fire data and radar data (vertically aggregated convective intensity and plume-top height) permits detailed examination of the fire's development and the localised pyroconvective contributions. Moreover, the combined analyses permit further scrutiny of the role of dynamic fire processes, such as mass spotting and the fire channelling phenomenon, in extreme fire development. In particular, the link between fire channelling and pyroCb development, which hitherto was established in only a single instance and in only a very qualitative way, is examined in greater depth and in more quantitative detail.

\section{Data}

It should be noted that all times (and thus dates) used in this paper are in UTC. Local time, Australian eastern summer time, is $\mathrm{UTC}+11 \mathrm{~h}$.

\subsection{Satellite data}

An initial examination of the areas of intense fire activity was conducted on LANDSAT archival imagery from USGS. One image that is both relatively cloud-free and free of scan-line correction problems showed the post-fire scars. An excerpt of the image is shown in Fig. 1d and clearly indicates leafless eucalypt canopy left behind by intense fire activity.

\subsection{Weather data}

Weather data were supplied by the Australian Bureau of Meteorology. This included automatic weather station (AWS) half-hourly observations and daily vertical profiles from radiosonde flights. Relevant weather data were recorded at Mt Boyce AWS (WMO Station Number 94743), Nullo Mountain AWS (94754), Penrith Lakes AWS (94763) and Cessnock Airport AWS (95771), and radiosonde data were recorded at Williamtown (94776). The radar data were recorded by the Newcastle radar. The locations of all of the above recording stations are shown in Fig. 1a.

Figure 2 shows time series plots of key weather measurements and fire indices for these stations. Fire behaviour estimates, using the equations of Noble et al. (1980), are based on the Forest Fire Danger Index. As no direct measurements of fuel moisture content (FMC) were available, FMC was described using the dimensionless fuel moisture 
(a)

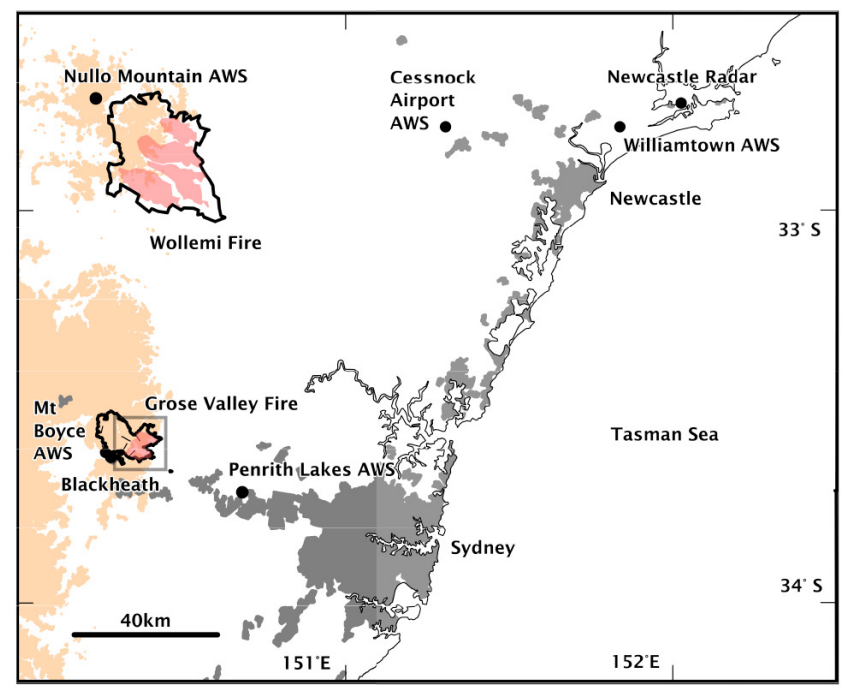

(c)

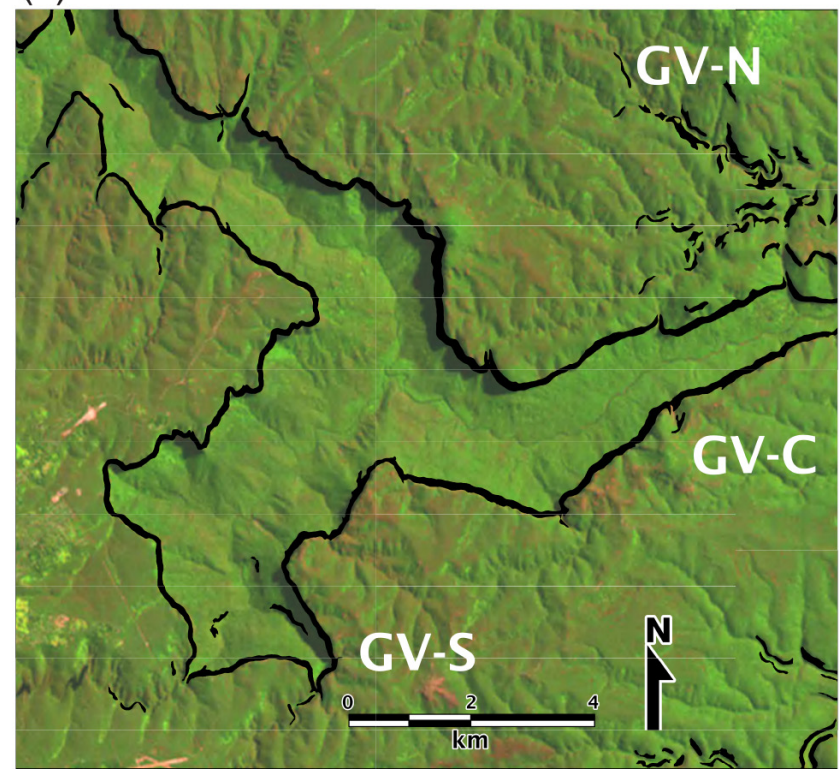

(b)

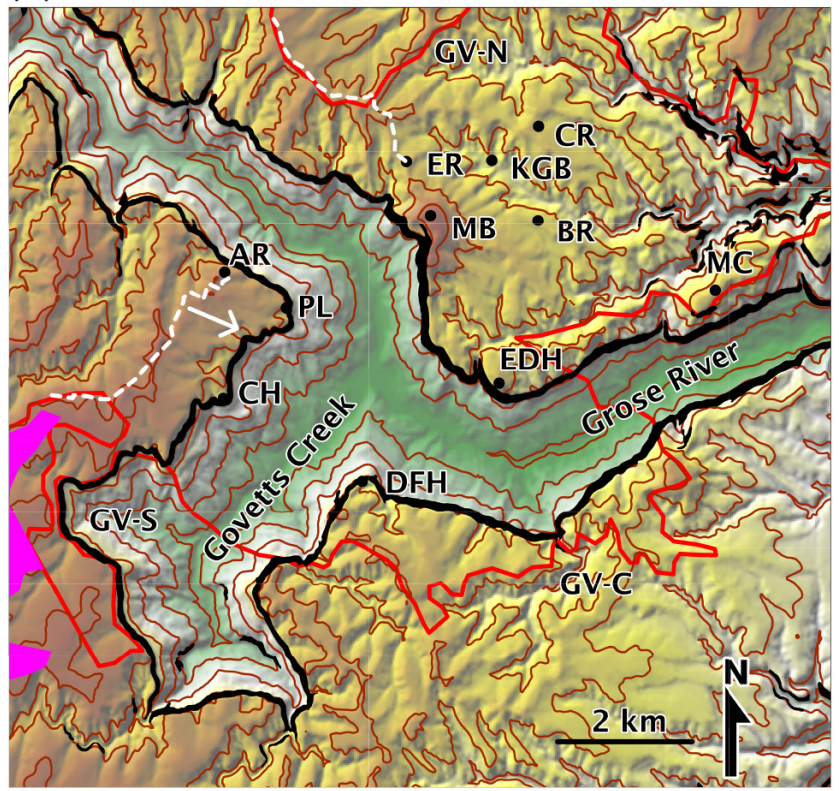

(d)

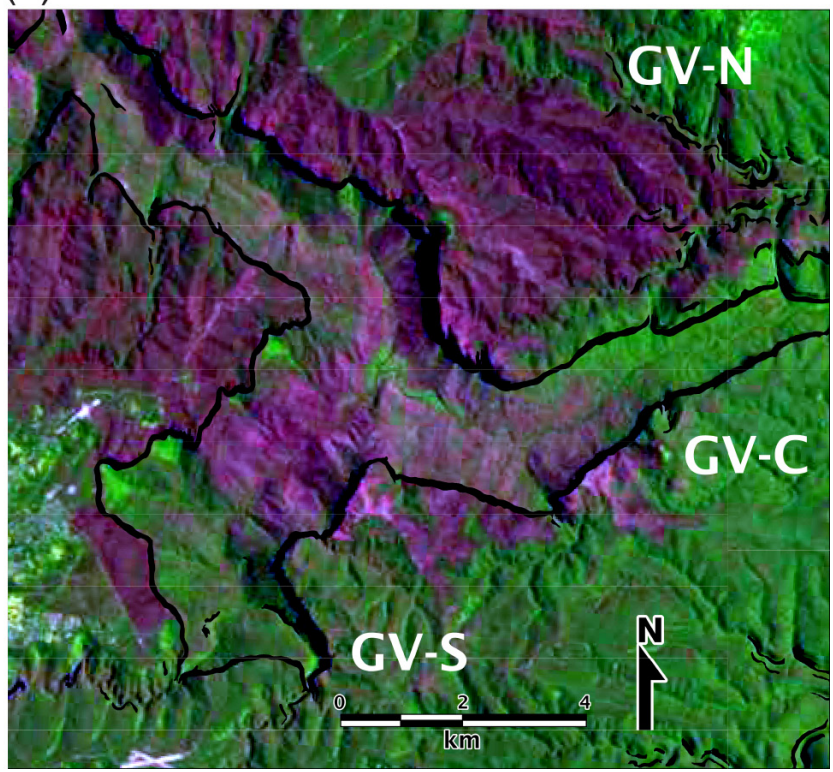

Figure 1. (a) Location map, showing: urban areas (grey), areas above $800 \mathrm{~m}$ a.s.l. (orange), burnt areas (black outline) and blow-up fire events (red). Also shown is the extent of the other figure panels. (b) Localities for the Grose Valley fire: the outskirts of the town of Blackheath (lower left) are shown in magenta, while the final fire area is outlined in red. The contour interval is $100 \mathrm{~m}$, major cliff lines are shown by heavy black lines. Elevation colours: $300 \mathrm{~m}$ is green; $600 \mathrm{~m}$ is white; $800 \mathrm{~m}$ is yellow; $1100 \mathrm{~m}$ is brown. The three fire areas are labelled GVN, GV-C and GV-S. Locality codes are: AR - Anvil Rock; BR - Banks Ridge; CH - Clarke Head; CR - Carmarthen Ridge; DFH - Du Faur Head; EDH - Edgeworth David Head; ER - Explorers Range; KGB - King Georges Brook; MB - Mt Banks; MC - Mt Caley; PL - Perrys Lookdown. The white dashed lines are the easterly containment lines early on 22 November. (c) Landsat imagery from 2002 . (d) Landsat imagery from 5 weeks after the Grose Valley fire. The intensity of the red is a measure of fire intensity (Landsat 5 Thematic Mapper, Path 9 Row 83, 27 December 2006). Major cliff lines are highlighted in (b), (c) and (d). 
index (FMI), which has been shown to produce reliable estimates of fuel moisture content in a variety of fine fuel types (Sharples et al., 2009; Sharples and McRae, 2011; Sharples and Matthews, 2011). In particular, Sharples et al. (2009) showed that FMI $\leq 5$ consistently corresponded to eucalypt litter moisture contents below 3-4\%, a predictor of elevated fire intensity and energy release.

Fromm et al. (2012, especially Fig. 15c) discussed the synoptic situation from the west, dominated by the passage, of a pressure trough linked to a cold front further south.

\subsection{Radar data}

The reflectivity data forming a full volume scan are available at 10 min resolution on 22 November. Computations from scan azimuth, elevations and range permit estimation of the maximum height of radar returns (the "echotop"; Fromm et al., 2012). We also employ vertical aggregated reflectivity, an indication of overall convective activity. The vertical aggregate of reflectivity is a simple summation of individual reflectivity values in the column at each reported range/azimuth location. Note that echoes below the nominal cloud-base altitude (taken to be $4 \mathrm{~km}$, based on the radiosonde profile at Williamtown) are attributable to non-hydrometeors such as debris lofted by the active fire (Lindley et al., 2011). Above the cloud base, stronger echoes are returned by hydrometeors, although these tend to be anomalously small (Rosenfeld, et al., 2007). In Fig. 6 we use a rain-rate product, which is derived from reflectivity.

\subsection{Multispectral line-scan data}

The New South Wales Rural Fire Service aircraft used the Daedalus 1268 ATM multispectral line scanner supplied by Air Target Services Pty Ltd, then under contract (Cook et al., 2009, Sharples et al., 2012). For each run, flown at heights of 7 to $8 \mathrm{~km}$, data acquisition took generally $10 \mathrm{~min}$ to complete. In some cases a number of contiguous passes were merged to provide coverage of the whole fire area.

Indicative colour samples are provided in the legend for Fig. 3; however, they relate to dynamically calibrated multispectral line scan products, taken in varying smoke scattering and absorption environments, which alter the pseudo-colour rendering.

\section{Results}

The available data for the Grose Valley fire allow detailed analysis of its dynamics. Figure $1 \mathrm{~b}$ shows localities relevant to this. These are referred to using codes explained in the figure caption.

\subsection{Fire spread prior to 21 November}

The Grose Valley fire began as two ignitions generally $10 \mathrm{~km}$ north of Mt Boyce that were detected on 14 November. The exact date and time of the ignitions are unknown (Cronstedt, 2006).

Prior to 21 November at 02:07 (line scan 116), the fire was spreading with a single bounding fire line (as seen in Fig. 3b) in a manner that could be deduced from fuel, terrain and weather data. It had gone out or been extinguished in places.

\subsection{Breakaway on 21 November}

A breakaway (AFAC, 2012) can be seen in Fig. 3b, north of Anvil Rock (AR). As a result of this, the containment line for the fire in the north-east had to be extended to the south-east of Explorers Range (ER). Figure 3c shows this as cold edge (line scan 117M, 22 November at 00:20) but also shows active fire edge extending past Banks Ridge (BR) to the southeast.

The fire burnt parallel to the cliff line, bypassed containment and became established on the plateau around ER, as might be expected given the terrain and the low FMI inferred from the weather observations (Fig. 2b).

The fire slowed significantly on the steep downslope runs off the range on 21 November at about 08:30, when the fire weather conditions began to ameliorate. At approximately this time the prevailing wind direction also changed from west-south-west to north-west (Mt Boyce, Fig. 2). The apparent lack of intense wind-driven fire activity at lower elevations in the Grose Valley suggests that these winds did not penetrate significantly down into the gorge; however, the fire on ER spread as a head fire down BR. On 21 November by 09:00 this part of the fire complex had burnt approximately 350 ha, with some lesser runs later in the night indicated by radar returns.

\subsection{Overnight foehn wind, 21 November}

Observations at Penrith Lakes AWS indicated the presence of a pronounced foehn effect over parts of the region, starting on 21 November at about 17:00, the night before the pyroCb blow ups. Indeed, the synoptic weather pattern was consistent with that associated with the development of foehn winds in south-east Australia (Sharples et al., 2010). As they noted, the approach of a synoptic front caused winds to align nearly perpendicular to parts of the Great Dividing Range. This primarily produced mechanical foehns and resultant elevated temperatures and depressed humidity levels in the lee of the terrain. An abrupt increase in temperature from 21.4 to $30.3^{\circ} \mathrm{C}$ with a complementary drop in relative humidity from 46 to $19 \%$ was recorded on 21 November over the period 16:30-17:00 at Penrith Lakes AWS (Fig. 2). Coincident with these changes was a change in wind direction 

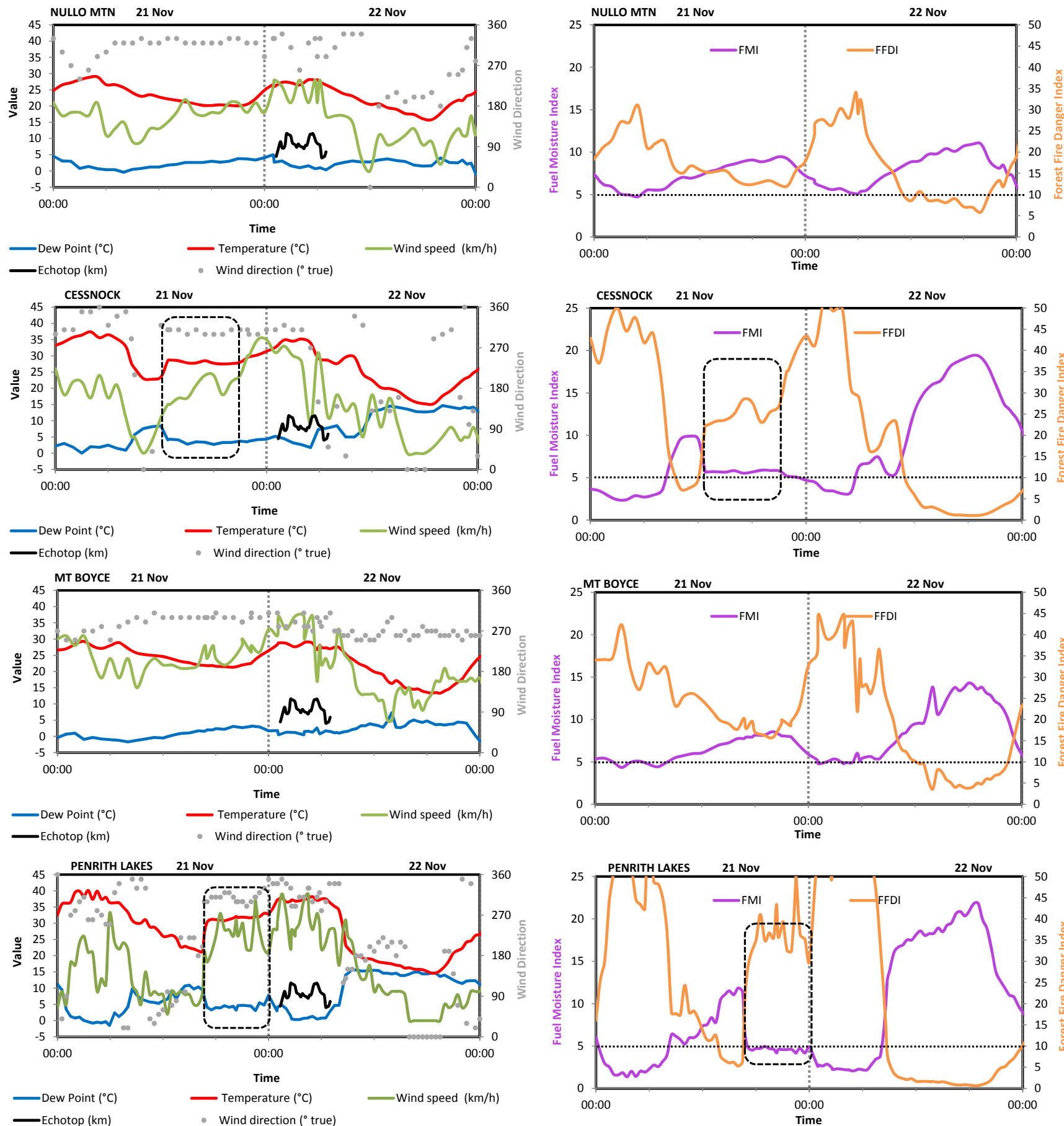

Figure 2. Weather graphs for four AWSs in the region, with surface weather (left-hand panels) and fire weather (right-hand panels). Dotted horizontal lines indicate FMI $=5$. For Cessnock and Penrith Lakes, the black dotted outlines highlight the nocturnal foehn event. The echotop time sequence (see Fig. 4 for detail) is included for cross-reference purposes. 
from south-west to north-west and an increase in wind speed from 9 to about $30 \mathrm{~km} \mathrm{~h}^{-1}$. This nocturnal foehn event would have significantly inhibited the usual moisture absorption by fuels that takes place overnight (Sharples, 2009; Sharples et al., 2010). It should be noted that while Mt Boyce AWS is close to the Grose Valley fire, it is on part of the terrain that would be generating, not experiencing, the foehn effect. The easterly AWSs (Penrith Lakes and Cessnock) are where the full effects of adiabatic processes would be expected. The fire ground, being up to $800 \mathrm{~m}$ lower than Mt Boyce AWS, might be expected to experience the effects of such a foehn wind event.

The fire also spread to the south, from the end of the containment line near AR. At the white arrow in Fig. 3c the fire crossed a creek line at the cliff top and moved uphill towards the south. The fire also dropped below the cliff line near Clarke Head $(\mathrm{CH})$ and began to spread slowly downslope to the east towards Govetts Creek.

\subsection{Widespread spotting in Grose Valley, 22 November:}

Figure $3 \mathrm{c}$ also shows the fire crossing the Grose River, approximately $1.5 \mathrm{~km}$ WSW of Mt Banks, after backing down the slopes below AR and Perrys Lookdown (PL). On 22 November at 01:00 the wind at Mt Boyce AWS shifted towards the west and increased in speed to above $35 \mathrm{~km} \mathrm{~h}^{-1}$. The change also brought the winds into closer alignment with the valley axis. On 22 November until 02:41 (line scan 126, Fig. 3d) the fire produced dense medium-range spot fires that extended $3.5 \mathrm{~km}$ downwind (in the area labelled "GV-C" in Fig. 1b), with a crosswind extent of approximately $2 \mathrm{~km}$. After merging, these spot fires covered an area of approximately 600 ha, as indicated in Fig. 3d. An extent of about 100 ha of this was on the plateau to the north-west of Edgeworth David Head, where the fire had merged with the right flank of the previous fire run over ER. Figure $3 d$ shows that the entire area burnt with high intensity, based on the relatively uniform spectral signature for active or decaying flame (Fig. 3, legend).

\subsection{Fire channelling, Banks Ridge, 22 November}

At a similar time, the left flank of the fire on the plateau (near King Georges Brook and Banks Ridge) exhibited spread with a notable northerly component, despite the west-north-west direction of the prevailing winds. This part of the fire complex is labelled "GV-N" in Fig. 1b. The relative intensity of the spectral signals indicates that this lateral spread produced higher rates of energy release compared to those inferred from Fig. 3c, $2.5 \mathrm{~h}$ earlier. The lateral fire propagation evident at GV-N is consistent with and best explained by the fire channelling phenomenon discussed by Sharples et al. (2012). Indeed, the steep lee slopes of the numerous side spurs leading north to Carmarthen Ridge satisfy the preconditions necessary for fire channelling to occur (Sharples et al., 2012).
The downwind extension of the flaming zone extending towards Mt Caley is also consistent with that seen in other fire channelling events (Sharples et al., 2012).

There was a spatial alignment between the inferred fire channelling event at GV-N, which was captured on 22 November at 02:41 in Fig. 3d, and the strong radar returns recorded after 02:20 (Fig. 4b), the convective core of which has been outlined in Fig. 3d. Figure $4 \mathrm{~b}$ indicates that the pyroconvective activity in the vicinity of GV-N started at approximately 01:30, and Fig. 4 a shows that the pyroconvective top exceeded an altitude of $9 \mathrm{~km}$ for approximately 40 min between 02:30 and 03:10. In this period the intense lateral spread associated with fire channelling can be inferred to have been underway. This establishes a compelling spatial and temporal connection between the intense lateral spread associated with fire channelling and the violent pyroconvective activity detected by the radar. As stated by Finney and McAllister (2011), a large fire source will produce a plume which experiences less entrainment and is thus able to reach greater heights. This is consistent with the GV-N situation. The significance of this linkage between fire activity and convection is further demonstrated in the later event at $\mathrm{CH}$, which will be discussed below.

\subsection{Fire channelling, Clarke Head, 22 November}

Figure 3e (line scan 127M, 22 November 05:00) shows that, after traversing the heavily dissected cliff line between PL and $\mathrm{CH}$, the fire exhibited rapid lateral spread towards the south-south-west along a $1.3 \mathrm{~km}$ length of cliff line. This part of the fire complex is labelled "GV-S" in Fig. 1b. The pattern of fire propagation depicted here is consistent with fire channelling, and the terrain in this vicinity meets the criteria necessary for fire channelling occurrence (Sharples et al., 2012). In addition to the lateral spread, the fire also spread downwind for $2.6 \mathrm{~km}$ across Govetts Creek, producing an active flaming area of approximately 400 ha. This expanse of active flame was constrained at the cliff line below Du Faur Head with some spotting for a further $1.7 \mathrm{~km}$ onto the plateau above. The southern flank of this part of the fire complex may be seen to be a series of merging spot fires, which is again consistent with other instances of fire channelling (Sharples et al., 2012).

The crosswind dimension of the flaming zone depicted to the south-south-west of $\mathrm{CH}$ in Fig. $3 \mathrm{e}$ was $1.3 \mathrm{~km}$, and assuming that the lateral spread was initiated immediately after $02: 41$, the inferred minimum rate of lateral spread is $0.6 \mathrm{~km} \mathrm{~h}^{-1}$. However, it is unlikely that a spectral signature corresponding to active flaming (i.e. bright yellow) would persist for over $2 \mathrm{~h}$ without cooling and so it is far more likely that the fire covered the crosswind distance over a time of the order of the burnout time for the dominant vegetation type in the area, i.e. $\sim 30 \mathrm{~min}$ or less. Indeed, Fig. $4 \mathrm{~b}$ indicates peak radar returns in the vicinity of GV-S sometime after 04:30, and if this is taken as an indicator of the onset of the lateral 

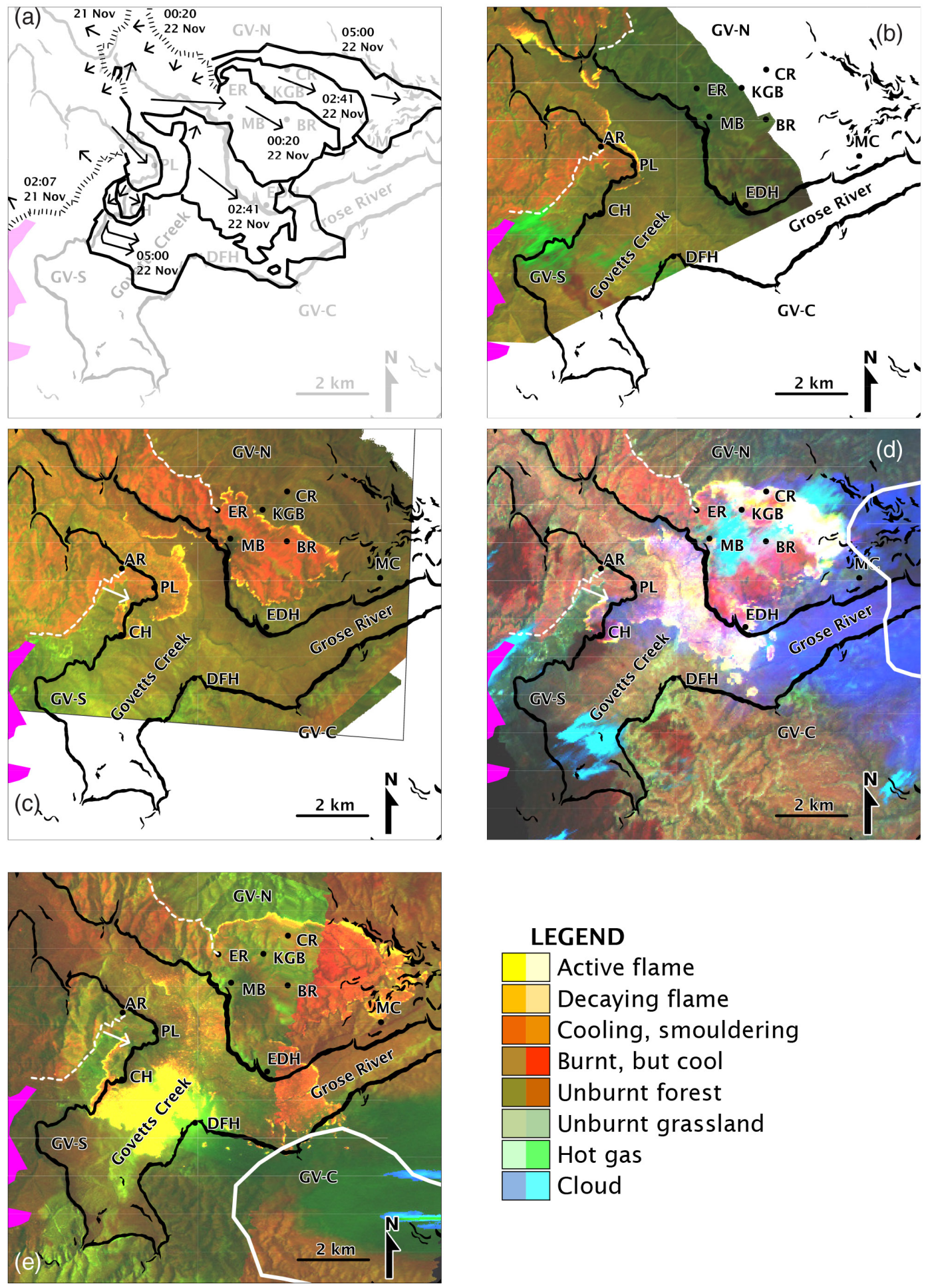

LEGEND
\begin{tabular}{|l|l}
\hline & Active flame \\
\hline \hline & Decaying flame \\
Cooling, smouldering \\
\hline \hline & Burnt, but cool \\
Unburnt forest \\
\hline \hline & Unburnt grassland \\
\hline \hline & Hot gas \\
\hline \hline & Cloud
\end{tabular}

Figure 3. (a) Summary of Grose Valley fire spread dynamics. Arrows show, in a stylised manner, fire spread directions. Cross-hatched lines indicate the control lines that were in place from time to time. (b, $\mathbf{c}, \mathbf{d}$ and $\mathbf{e}$ ) Line-scan excerpts. Control lines are shown by white dashed lines. (b) Run 116, flown on 21 November, 02:07. (c) Run 117M, flown on 22 November, 00:20. The white arrow near PL is the critical point where fire was able to spread along the cliff top into the GV-S area. (d) Run 126, flown on 22 November, 02:41. The core of the contemporaneous radar reflectivity pattern is outlined in white. (e) Run 127M, flown on 22 November, around 05:00. The core of the contemporaneous radar reflectivity pattern is outlined in white. (Legend) Line-scan thematic legend; note the colours are indicative only, as there is considerable variation due to smoke density. Some colours arise from a composite of surface and atmospheric features. 


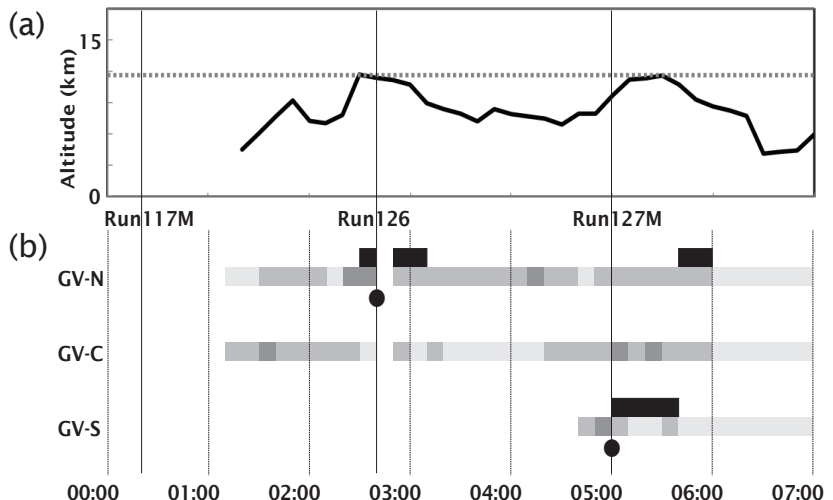

Figure 4. Time series analysis of localised convective activity from radar data. The data set spans 22 November, 00:00 to 07:00 only. (a) Echotop time series, from Newcastle radar data, for Grose Valley fire. The horizontal dotted line indicates the tropopause altitude determined from the Williamtown radiosonde measurement on 22 November at 00:00 (12 km a.s.1.; Fromm et al., 2012). (b) Radar summaries. Black bars indicate pyro-tops over $9 \mathrm{~km}$ a.s.l. Grey bars represent $10 \mathrm{~min}$ typical reflectivity, with the grey shade indicating reflectivity class values. Vertical black lines indicate key overhead remote-sensing passes. The black dots indicate identified fire channelling events.

spread then the estimate for the rate of lateral spread can be revised to $2.6 \mathrm{~km} \mathrm{~h}^{-1}$. This latter estimate of the lateral rate of spread is of a similar order to that inferred in other cases of fire channelling using overlapping line-scan data (Sharples et al., 2012).

Figure $3 \mathrm{e}$ illustrates the spatial alignment between the fire channelling event at GV-S and the location of the strong radar returns used to populate Fig. 4 . Figure 4 indicates that this plume developed into a significant pyroCb that exceeded $9 \mathrm{~km}$ in height between 05:00 and 05:40. Moreover, Fig. 4a confirms that the radar detected an abrupt increase in the echotop altitude at approximately the same time as the fire channelling event at GV-S was underway. This pyroCb activity associated with the fire channelling event ultimately registered echotops near the tropopause at $\sim 11.5 \mathrm{~km}$.

It is estimated that $650 \mathrm{ha}$ burnt within $2 \mathrm{~h}$ at GV-S, yielding an estimated energy release of around $2 \times 10^{11} \mathrm{~kJ}$, broadly comparable to values estimated for the Canberra fire in 2003 (Fromm et al., 2006). This and the entrainment concepts in Finney and McAllister (2011) support the connection between the fire and the pyroCb.

\section{Discussion}

"Blow up" has been used as a term for unexpected fire escalation and has been discussed on a technical level by Arnold and Buck (1954), Byram (1954), Steiner (1976) and McRae and Sharples (2013). Byram suggested that the wind profile is a contributor to blow-up potential. The vertical pro-

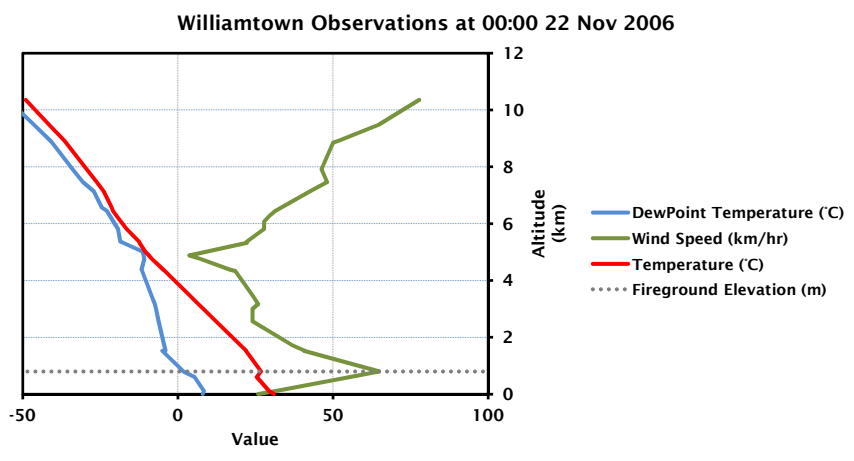

Figure 5. Radiosonde data from Williamtown, 22 November, 00:00. The dotted line indicates the elevation of the GVN fire area.

file recorded at Williamtown (the closest relevant observation site), shown in Fig. 5, indicates a wind-velocity maximum at about $1 \mathrm{~km}$ above the observation site's elevation compared to a jet point (Byram, 1954).

Other work on blow-up fires has focussed on the role of vertical stability (Haines, 1988; Mills, 2008; Mills and McCaw, 2010). As discussed by Fromm et al. (2012), the CHaines value was elevated during these events. Relevance to the stability component of the C-Haines was a band of small dry thunderstorms that passed over the region on the afternoon of 22 November that ignited new fires in the region of the Wollemi fire by means of lightning strikes (NSW Rural Fire Service, 2006). Radar data show that this band passed over the Grose Valley fire at about 03:20 and the Wollemi fire at 04:20. Figure 6 shows a radar image from 05:30.

The preceding analyses indicate that future forecasts of the occurrence of a blow-up event may need to consider some combinations of the fire, weather and terrain factors identified here (and their interactions): the absence of a fine fuel moistening phase during the preceding night; the maximum fire danger at the surface and its relation to the typical diurnal cycle; a jet point in the wind profile; the terrain on which the fire is burning (ruggedness) with respect to its orientation to the prevailing wind; the arrival time of fire in critical parts of the landscape; and the passage of pressure troughs, or other sources of atmospheric instability, that might exacerbate fire intensity. This is reflected in the model framework proposed by McRae and Sharples (2013).

Direct measurement of some of the important dynamics of a complex fire burning in a rugged landscape demonstrated that a variety of mechanisms may produce the required fire characteristics for violent pyroconvection to commence, but the most significant development of pyroCbs here occurred in connection with the fire channelling phenomenon.

Recent numerical modelling by Simpson et al. (2013, 2014) has demonstrated that pyrogenic vertical vorticity can produce atypical lateral spread consistent with this. Future work may shed new light on the physical mechanisms underlying the Grose Valley fire. 


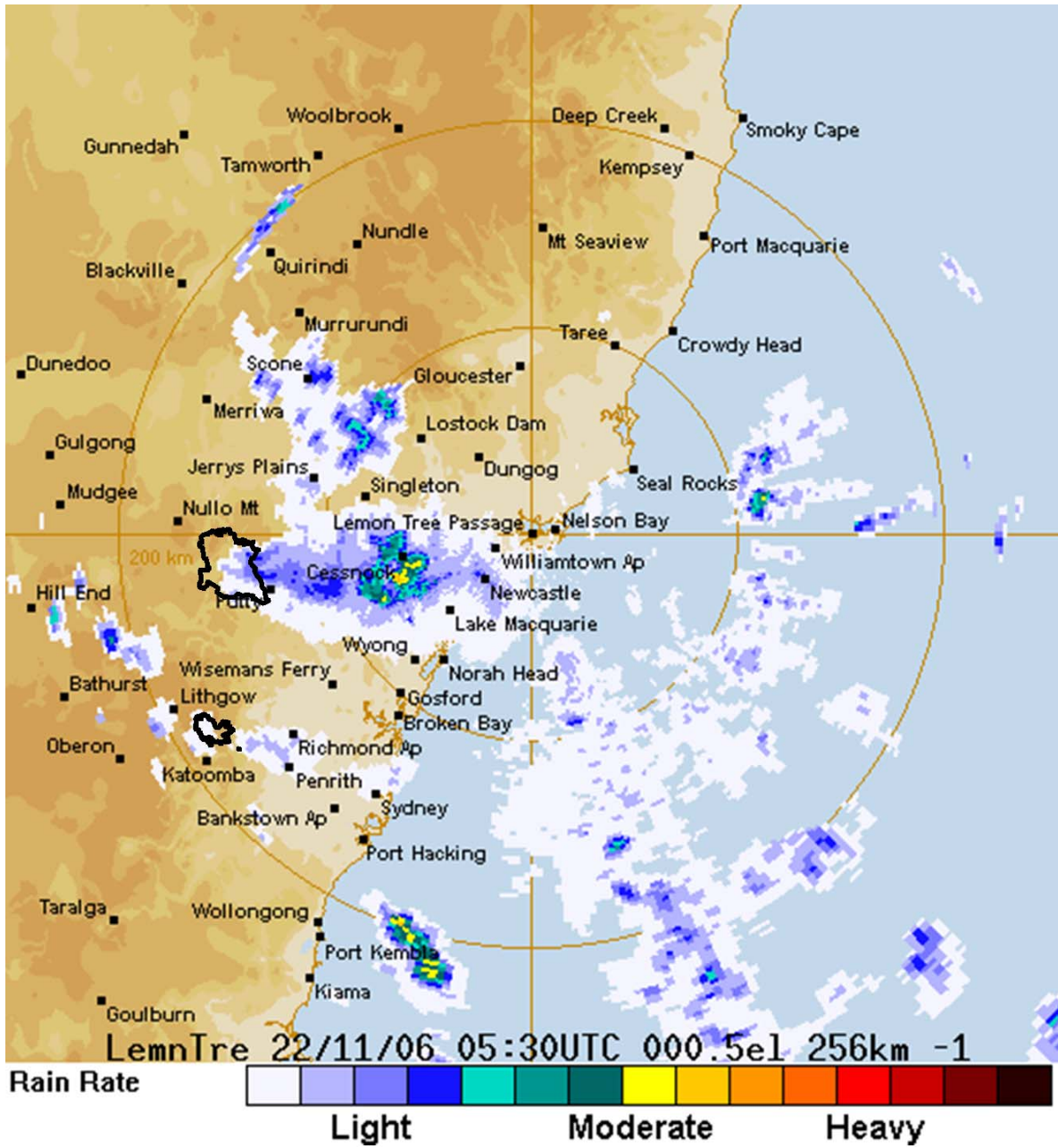

Figure 6. Newcastle (Lemon Tree Passage) radar rain-rate product for 22 November 05:30. The black outlines are the burnt areas. The diagonal band of instability that is about to pass over the radar site from the west (situated between Scone and Lake Macquarie and extending to the SE into the Tasman Sea) is strongly interacting with the plume from the Wollemi fire (between Putty and Cessnock).

\section{Conclusions}

As noted by Fromm et al. (2010), there is a need for more case studies of blow-up events to improve our understanding; however, as we have shown here for this event, these must be based on sound fire and weather data.

In this study we have shown that atypical modes of fire propagation in a rugged landscape, primarily fire channelling exacerbated by antecedent anomalous fire weather arising from a foehn wind occurrence, were a major factor in these particular pyroCb blow ups.
We have shown that from time to time the evolution of a fire may produce localised surges in intensity which, in the right instability setting, can produce pulses of violent pyroconvection. Fromm et al. (2012) showed there were only small differences between fire weather on this day and the preceding day. This makes it clear that for fire managers to ensure the safety of fire crews and the public, they need to think beyond established practices and assess the potential for atypical fire dynamics. 


\section{Appendix A}

Table A1. List of events in Australia which, based on available evidence, are known to have been, or are strongly suspected to have been, pyroCb occurrences.

\begin{tabular}{|c|c|c|c|c|c|}
\hline Year & Date & State & Location/fire & Longitude $\left({ }^{\circ}\right)$ & Latitude $\left({ }^{\circ}\right)$ \\
\hline 1995 & $25 \mathrm{Feb}$ & Vic & Berringa & 143.7 & -37.8 \\
\hline 1998 & 2 Jan & Vic & Caledonia River & 146.8 & -37.5 \\
\hline 2001 & 18 Jan & WA & Splinter Rock & 122.9 & -33.1 \\
\hline 2002 & $17 \mathrm{Dec}$ & Victoria & Big Desert & 141 & -35.7 \\
\hline \multirow[t]{8}{*}{2003} & 17 Jan & ACT & Stockyard Spur & 148.9 & -35.5 \\
\hline & 18 Jan & NSW & Broken Cart fire & 148.6 & -35.5 \\
\hline & $18 \mathrm{Jan}$ & ACT & Stockyard Complex & 148.9 & -35.6 \\
\hline & $18 \mathrm{Jan}$ & ACT & Stockyard Complex & 148.8 & -35.5 \\
\hline & 18 Jan & NSW & McIntyres Hut fire & 148.8 & -35.3 \\
\hline & 18 Jan & NSW & Alpine Complex & 148.4 & -36 \\
\hline & 26 Jan & NSW/Vic & Alpine Complex & [147] & {$[-37]$} \\
\hline & 30 Jan & NSW/Vic & Alpine Complex & {$[148]$} & {$[-37]$} \\
\hline \multirow[t]{7}{*}{2006} & 19 Jan & Victoria & Grampians & 142.4 & -37.3 \\
\hline & 22 Nov & NSW & Wollemi & 150.3 & -32.8 \\
\hline & 22 Nov & NSW & Grose Valley & 150.3 & -33.6 \\
\hline & 29 Nov & NSW & Pilliga & 149.2 & -31 \\
\hline & $6 \mathrm{Dec}$ & Victoria & Alpine Complex & 146.5 & -36.8 \\
\hline & $14 \mathrm{Dec}$ & Victoria & Alpine Complex & 146.2 & -37.5 \\
\hline & $16 \mathrm{Dec}$ & Victoria & Alpine Complex & {$[147]$} & {$[-38]$} \\
\hline 2007 & $16 \mathrm{Jan}$ & Victoria & Alpine Complex & 146.4 & -37.1 \\
\hline \multirow[t]{4}{*}{2009} & $7 \mathrm{Feb}$ & Victoria & Kilmore Gap & 145.1 & -37.2 \\
\hline & $7 \mathrm{Feb}$ & Victoria & Murrindindi & 145.5 & -37.4 \\
\hline & $7 \mathrm{Feb}$ & Victoria & Bunyip & 145.7 & -37.9 \\
\hline & $7 \mathrm{Feb}$ & Victoria & Beechworth & 146.7 & -36.4 \\
\hline 2010 & $18 \mathrm{Feb}$ & WA & Esperance & 122.2 & -33.1 \\
\hline \multirow[t]{6}{*}{2012} & $18 \mathrm{Oct}$ & WA & Deserts & 125.1 & -27.3 \\
\hline & $18 \mathrm{Oct}$ & WA & Deserts & 124.8 & -26.5 \\
\hline & $18 \mathrm{Oct}$ & WA & Deserts & 126.7 & -27.4 \\
\hline & $18 \mathrm{Oct}$ & WA & Deserts & 126 & -27.6 \\
\hline & $18 \mathrm{Oct}$ & WA & Deserts & 126.7 & -28.3 \\
\hline & 29 Oct & WA & Deserts & 122.8 & -28.5 \\
\hline \multirow[t]{2}{*}{2013} & 4 Jan & Tasmania & Dunalley & 147.7 & -42.9 \\
\hline & 13 Jan & NSW & Wambelong & 149 & -31.3 \\
\hline \multirow[t]{3}{*}{2014} & 16 Jan & Victoria & Grampians & 142.4 & -37 \\
\hline & 17 Jan & Victoria & Grampians & 142.3 & -37.1 \\
\hline & $9 \mathrm{Feb}$ & Victoria & East Gippsland & 145.5 & -37.3 \\
\hline
\end{tabular}

Note that geographic coordinates are accurate to $0.1^{\circ}$ only and those in brackets are approximate.

Table A2. List of events in Australia which are currently under investigation as candidates for pyroCb occurrences.

\begin{tabular}{rrllrr}
\hline Year & Date & State & Location/fire & Longitude $\left(^{\circ}\right)$ & Latitude $\left(^{\circ}\right)$ \\
\hline 1983 & 16 Feb & Vic/SA & Ash Wednesday & {$[144]$} & {$[-38]$} \\
1994 & 23 Jan & WA & WSW of Kalgoorlie & {$[120]$} & {$[-32]$} \\
\hline
\end{tabular}

Note that geographic coordinates are accurate to $0.1^{\circ}$ only and those in brackets are approximate. 
Acknowledgements. We thank: Tony Bannister, Bureau of Meteorology, for the level 2 radar data and AWS hourly surface observations; Laurence McCoy, NSW Rural Fire Service, for arranging access to the line scans (all line scans are courtesy of NSW Rural Fire Service GIS Section); Robert Norman, Air Target Services Pty Ltd; and David Crust, Area Manager, Mudgee, NSW National Parks and Wildlife Service.

Edited by: R. Lasaponara

Reviewed by: B. Potter and two anonymous referees

\section{References}

AFAC: Bushfire Glossary, AFAC Limited, Melbourne, Australia, 36 pp., 2012.

American Meteorological Society: Glossary of Meteorology, available at: http://glossary.ametsoc.org/wiki/Pyrocumulonimbus (last access: 24 April 2014), 2013.

Arnold, R. K. and Buck, C. C.: Blow-Up fires - Silviculture or Weather Problems? J. Forestry, 52, 408-411, 1954.

Byram, G. M.: Atmospheric Conditions Related to Blowup Fires, Southeastern Forest Experimental Station Paper, Asheville, NC, Station Paper 35, 33 pp., 1954.

Cook, R., Walker, A., and Wilkes, S.: Airborne fire intelligence, in: Innovations in remote sensing and photogrammetry, edited by: Jones, S. and Reinke, K., Springer, Heidelberg, Germany, 239$254,2009$.

Cronstedt, M.: Lawson's Long Alley Section 44 Incident Controller's Report, Prepared for New South Wales Rural Fire Service, Sydney, New South Wales, Australia, 26 pp., 2006.

Finney, M. A. and McAllister, S. S.: A Review of Fire Interactions and Mass Fires, Journal of Combustion, 548328, 14 pp., doi:10.1155/2011/548328, 2011.

Fromm, M., Bevilacqua, R., Stocks, B., and Servranckx, R.: New Directions: Transport to the Stratosphere: Add Fire-Convection to Volcanoes, Atmos. Environ., 38, 163-165, 2004.

Fromm, M., Tupper, A., Rosenfeld, D., Servrancx, R., and McRae, R.: Violent pyro-convective storm devastates Australia's capital and pollutes the stratosphere, Geophys. Res. Lett., 33, L05815, doi:10.1029/2005GL025161, 2006.

Fromm, M., Lindsey, D. T., Servranckx, R., Yue, G., Trickl, T., Sica, R., Doucet, P., and Godin-Beekmann, S.: The Untold Story of Pyrocumulonimbus, B. Am. Meteorol. Soc., 91, 1193-1209, 2010.

Fromm, M. McRae, R., Sharples, J., and Kablick, G.: Pyrocumulonimbus Pair in Wollemi and Blue Mountains National Parks, 22 November 2006, Aust. Meteorol. Oceanogr. J., 62, 117-126, 2012.

Haines, D. A.: A lower atmosphere severity index for wildland fires, National Weather Digest, 13, 23-27, 1988.

Jost, H.-J., Drdla, K., Stohl, A., Pfister, L., Loewenstein, J. P., Hudson, P. K., Murphy, D. M., Cziczo, D. J., Fromm, M., Bui, T. P., Dean-Day, J., Gerbig, C., Mahoney, M. J., Richard, E. C., Spichtinger, N., Pittman, J. V., Weinstock, E. M., Wilson, J. C., and Xuerei, I.: In-situ observations of mid-latitude forest fire plumes deep in the stratosphere, Geophys. Res. Lett., 31, L11101, doi:10.1029/2003GL019253, 2004.

Kahn, R. A., Chen, Y., Nelson, D. L., Leung, F.-Y., Li, Q., Diner, D. J., and Logan, J. A.: Wildfire smoke injection heights:
Two perspectives from space, Geophys. Res. Lett., 35, L04809, doi:10.1029/2007GL032165, 2008.

Lavoué, D., Liousse, C., Cachier, H., Stocks, B. J., and Goldammer, J. G.: Modeling of carbonaceous particle emitted by boreal and temperate wildfires at northern latitudes, J. Geophys. Res.Atmos., 105, 26871-26890, 2000.

Lindley,T., Vitale, J., Burgett, W., and Beierle, M.: Proximity meteorological observations for wind-driven grassland wildfire starts on the southern high plains, Electron. J. Severe Storms Meteorol., 6, 1-27, 2011.

Mazzoni, D., Logan, J. A., Diner, D., Kahn, R., Tong, L., and Li, Q.: A data-mining approach to associating MISR smoke plume heights with MODIS fire measurements, Remote Sens. Environ., 107, 138-148, 2007.

McRae, R. and Sharples, J.: A conceptual model for assessing the risk posed by extreme bushfires, Aust. J. Emerg. Manage., 26, 47-53, 2011.

McRae, R. and Sharples, J.: A process model for forecasting conditions conducive to blow-up fire events, Proceedings of the 2013 MODSIM Conference, Adelaide, Australia, 1-6 December, 187192, 2013.

Mills, G. A.: On the sub-synoptic scale meteorology of two extreme fire weather days during the Eastern Australian fires of January 2003, Aust. Meteorol. Mag., 54, 265-290, 2005.

Mills, G. A.: Abrupt surface drying and fire weather Part 2: a preliminary synoptic climatology in the forested areas of southern Australia, Aust. Meteorol. Mag., 57, 311-328, 2008.

Mills, G .A. and McCaw, L.: Atmospheric Stability Environments and Fire Weather in Australia - extending the Haines Index, Report 20, Centre for Australian Weather and Climate Research, Melbourne, Victoria, 158 pp., 2010.

Nairn, G.: A Nation Charred: Inquiry into the Recent Australian Bushfires, The Parliament of the Commonwealth of Australia, Canberra, 500 pp., 2003.

New South Wales Rural Fire Service: Wollemi Western division Section 44 Report, New South Wales Rural Fire Service, Sydney, New South Wales, 20 pp., 2006.

Noble, I. R., Bary, G. A. V., and Gill, A. M.: McArthur's fire-danger meters expressed as equations, Aust. J. Ecol., 5, 201-203, 1980.

Potter, B. E.: A dynamics based view of atmosphere-fire interactions, Int. J. Wildland Fire, 11, 247-255, 2002.

Potter, B. E., Charney, J. J., Heilmen, W. E., and Bian, X.: Advances in fire convection dynamics, in: Advancing the Fundamental Sciences: Proceedings of the Forest Service National Earth Sciences Conference, edited by: Furniss, M., Clifton, C., and Ronnenberg K., San Diego, CA, USA, 18-22 October 2004, 2007.

Rosenfeld, D., Fromm, M., Trentmann, J., Luderer, G., Andreae, M. O., and Servranckx, R.: The Chisholm firestorm: observed microstructure, precipitation and lightning activity of a pyro-cumulonimbus, Atmos. Chem. Phys., 7, 645-659, doi:10.5194/acp-7-645-2007, 2007.

Sharples, J. J.: An overview of mountain meteorological effects relevant to fire behaviour and bushfire risk, Int. J. Wildland Fire, 18, 737-754, 2009.

Sharples, J. J. and Matthews, S.: Evaluation of some simplified models for predicting the moisture content of fine, dead fuels, in: MODSIM2011, 19th International Congress on Modelling and Simulation, edited by: Chan, F., Marinova, D., and Anderssen, R. S., Modelling and Simulation Society of Australia and New 
Zealand, Perth, Western Australia, 12-16 December 2011, 242248, 2011.

Sharples, J .J. and McRae, R. H. D.: Evaluation of a very simple model for predicting the moisture content of eucalypt litter, Int. J. Wildland Fire, 20, 1000-1005, 2011.

Sharples, J. J., McRae, R. H. D., Weber, R. O., and Gill, A. M.: A simple index for assessing fuel moisture content, Environm. Modell. Software, 24, 637-646, 2009.

Sharples, J. J., Mills, G. A., McRae, R. H. D., and Weber, R. O.: Foehn-like winds and elevated fire danger conditions in southeastern Australia, J. Appl. Meteorol. Climatol., 49, 1067-1095, 2010.

Sharples, J. J., McRae, R. H. D., and Wilkes, S. R.: Wind-terrain effects on the propagation of wildfires in rugged terrain: fire channelling, Int. J. Wildland Fire, 21, 282-296, 2012.

Simpson, C. C., Sharples, J., Evans, J., and McCabe, M.: Large eddy simulation of atypical wildland fire spread on leeward slopes, Int. J. Wildland Fire, 22, 282-296, 2013.

Simpson, C. C., Sharples, J. J., and Evans, J. P.: Resolving vorticity-driven lateral fire spread using the WRF-Fire coupled atmosphere-fire numerical model, Nat. Hazards Earth Syst. Sci., 14, 2359-2371, doi:10.5194/nhess-14-2359-2014, 2014.
Smith, R.: Report of the Key Issues Identified from Operational Reviews of Major Fires in Victoria 2006/07, Melbourne, Department of Sustainability and Environment, Australia, 97 pp., 2007.

Steiner, J. T.: Blow-Up fires - The Byram Wind Profile, Aust. Meteorol. Mag., 24, 139-142, 1976.

Teague, B., McLeod, R., and Pascoe, S.: 2009 Victorian Bushfires Royal Commission Final Report, State of Victoria, Melbourne, Victoria, Australia, 2010.

Trentmann, J., Luderer, G., Winterrath, T., Fromm, M. D., Servranckx, R., Textor, C., Herzog, M., Graf, H.-F., and Andreae, M. O.: Modeling of biomass smoke injection into the lower stratosphere by a large forest fire (Part I): reference simulation, Atmos. Chem. Phys., 6, 5247-5260, doi:10.5194/acp-65247-2006, 2006.

Val Martin, M., Logan, J. A., Kahn, R. A., Leung, F.-Y., Nelson, D. L., and Diner, D. J.: Smoke injection heights from fires in North America: analysis of 5 years of satellite observations, Atmos. Chem. Phys., 10, 1491-1510, doi:10.5194/acp-10-14912010, 2010. 